\title{
ALK Inhibitor WX-0593
}

National Cancer Institute

\section{Source}

National Cancer Institute. ALK Inhibitor WX-0593. NCI Thesaurus. Code C154279.

An orally available, small molecule inhibitor of the receptor tyrosine kinase (RTK) anaplastic lymphoma kinase (ALK), with potential antineoplastic activity. Upon oral administration, WX-0593 binds to and inhibits ALK tyrosine kinase, ALK fusion proteins, ALK point mutation variants ALK L1196M, ALK C1156Y, and EGFR L858R/T790M. Inhibition of ALK leads to the disruption of ALK-mediated signaling and the inhibition of cell growth in ALK-expressing tumor cells. ALK belongs to the insulin receptor superfamily and plays an important role in nervous system development. ALK is not expressed in healthy adult human tissue but ALK dysregulation and gene rearrangements are associated with a series of tumors. Additionally, ALK mutations are associated with acquired resistance to small molecule tyrosine kinase inhibitors. 